\title{
The Contribution of the EU to the Implementation of the Global Compacts: Legal Certainty for People on the Move as a Global Public Good
}

\author{
Carmen PÉREZGo\ZÁLEZ
}

\begin{abstract}
This multilateralism served a high purpose: to secure the freedoms of people everwwere (that is, people in the lands of the cooperation
\end{abstract} countries as well as in olher lands) and to engage in a common (that is to say, universal) struggle.'

\begin{abstract}
1bstract: This work aims to analyze the role of the EU and its Member States in implementing the U V Global Compacts from a specific approach: the theory of global public goods. In particular, it aims to eyplore the incentives EU and its Member States would have for agreeing on a European regime prov iding safe and legal pathwavs for migrants and people in need of international protection heading to the European territory. Although a variety of international instruments contain both the right to leave any country, including one's own country, and the right to seek international protection, up to now the International Community has failed in its attempt of providing legal certainty for people on the move. This article considers that a global public good approach would fuel the indispensable political consensus to do so.
\end{abstract}

Keywords: U G Global Compacts-security in migration- legal certainty people on the move people in need of international protectionglobal public goods- aggregate efforts- EU migration and ass lum policy.

\section{(A) INTRODUCTORY REM IRKS}

Few human phenomena have been more perceived as problematic, more open to political discussion and legal control, and more anxiously afraid that human mobility across borders. Although it is considered a major concern nowadays, international legal response is still disappointing. Establishing an international framework providing legal and safe migratory channels is widely considered as being one of the main challenges of our $2 \mathrm{r}^{\text {st }}$ century international community. At the same lime, security in migration, which has been considered a priority belonging to the area of the protection of human rights, with regard to the connection with the universal right to security, which is rooted in human dignity ${ }^{22}$ has been identified as a key priority by international human rights monitoring bodies. Despite its importance, the issue remains poorly understood within (...) policy circles'? It is notorious that, when facing the most important refugee

ar Irlicle published on.31 December 2org

Issociate Professor of Public International Law, Universitv Carlos III de Madrid. Mail: carmen.perez ${ }^{a}$ uczm.es. This article was written within the contevt of the research project "The European Union's policies on ass lum: confluences between the internal and the external dimensions' (DER-2017-82/66-R), funded by the Spanish Vinistry of Economy and Competitiveness and FEDER, as well as the Jean Vonnet Chair EU Economic and Legal Integration for People, E IC/ $\mathrm{AO}_{2} 2016$ (2017-2020). All websiles last accessed 7 Vorember 2019.

S. Barrell, Why Cooperale?' The Incentive to Supply Global Public Goods (O)ford, Odford University Press, 2007) at 198.

2. M. Kosińska and B. Vikołajcank, 'Does the Right to Vigration Security Mready Evist?' Considerations from the Perspective of the EU's Legal Sistemi, 21 European Journal of Vigration and Law (2019) 83-116, at 84.

3 A. Belts, 'Introduction: Global Vigration Governance', in A. Betts (ed), Gilobal Vigration Governance (OU P, Oxford, 20II) I, al 3 . 
crisis since $\mathbf{W}$ orld Word II, European States had failed to provide safe protection channels for those fleeing the brutal Syrian conflict. The absence of legal mechanisms for securing access to international protection procedures and regular labour status forces people on the move to resort to criminal networks and under take a dangerous journey which often put their lives at risk. ${ }^{4}$

In a seemingly self-contradictory way, States have agreed on guarantying a set of rights related to individual's freedom of movement. Thus, from an international legal point of view, a range of international instruments contain both the right to leave any country, including one's own country, ${ }^{j}$ and the right to seek international protection. ${ }^{6}$ Itowever, freedom of movement is limited, since those individuals don't have the right to decide their country of residence outside of the requirements imposed by national laws on a unilateral basis, ${ }^{7}$ including those implementing the obligations contained in the $195^{1}$ Geneva Convention on the Status of Refugees ${ }^{8}$ and its 1967 Protocol. ${ }^{9}$ As a consequence of that, the international regime for human mobility and international protection is both fragmented and inadequate." In this context, the United Xations (U V) Global Compacts represent the most recent attempt of the international community to provide coherence to the international governance of migratory flows."

This work aims to analyse the role of the European Union (EU) and its Member States in implementing the U Y Global Compacts from a specific approach: the theory of global public goods. In particular, it aims to explore the incentives EU and its Member States would have for agreeing on a

\footnotetext{
i According to the International Organization for Migration (IOM) project 'Missing migrants. Tracking deaths along migratory routes, a total of t.159 deaths have been recorded in the Mediterranean in 2019. Data are available electronically at hllps: / missingmigrants.iom.int/region/mediterranean, accessed 7 November 2019.

5 See art. 12 of the Universal Declaration of Iluman Rights (U DIIR), G 1 Res. 217 A (adopted so December 19/9); art. 12.1 and 2 of the International Covenant on Civil and Political Right (adopted 16 I)ecember ig66, entered into force 23 March ig76), art. 2.1 of the European Convention for the Protection of I Iuman Rights and Fundamental Freedoms (ECIIR), ETS No.oo5 (adopted / Vovember 1950, entered into force 3 September 1953); art. 22.2 of the American Convention on Ituman Rights (adopted 22 Vovember ig69, entered into force I8 July 1978); and art. 12.2 of the African Charter on Ituman and People's Rights (adopted 27 June ig8 8 , entered into force 21 October ig 85 ).

6 See art. 1/.1 U DIIR; art. 22.7 of the American Convention on Ituman Rights; art. 12.3 of the African Charter on IIuman and Peoples Rights; and art. I8 of the Charter of Fundamental Rights of the EU (O.J $2000 \mathrm{C}_{3} 6 / 1$ ). It is very interesting the recent Inter- American Court of Iluman Rights (I ACrtIIR) Advisory Opinion on the institution of asylum, and its recognition as a human right under the Inter-American System of Protection (interpretation and scope of Articles $5,22(7)$ and $22(8)$ in relation to Article s(ı) of the American Convention on Ituman Rights), OC-2j 18 of zo Mas 302018.

7 Nthough conditioned to the fulfilment of the obligations imposed by International Ilumans Rights Law (IIIRL), International law assumes that States has the sovereign right to enact and implement migration and border security measures.

8 Adopted 28 July r9j, entered into force 22 April 195\%.

9 Adopted by G 1 Res. $2198(\mathrm{XXI})$ of 16 December ig66, entered into force / October ig 67.

1) It has been said that '(...) no formal or coherent framework has been developed by the U N within which states' responses to international migration should be framed': E. Guild and S., 'Grant Vigration Governance in the U Y: What is the Global Compact and What does it mean?', Queen Wary School of Law Legal Studies Research Paper No. 2.j2/20r7, published on ro January 2017.

"The Global Compact for Safe, Orderly and Regular Migration (GCM) was adopted on ro December 2018 at an Intergovernmental Conference held in Marrakech and endorsed by the U \ General Assembly (U \G I) on ig December 2018. The Global Compact on Refugees (GCR) was endorsed by the U VGI on iz December 2or8. Both are available electronically here.
} 
European well planned, consistent and rational regime providing safe and legal pathways for migrants ${ }^{12}$ and people in need of international protection. ${ }^{3}$ This perspective could help to overeome the political concerns about the consequences of an unequal distribution of efforts and burdens among Member States,'í which are fuelling the arguments of extreme right-wing political parties in EU Member States and threating the continuity of the integration process.

This paper is organized as follows. It will first refer to the legal nature of the Global Compacts. I will outline how the Global Compacts underline the need to develop and facilitate mobility and legal admission channels for economic migrants and refugees people in need of international protection (B). Second, I will analyse the role of the EU and its Member States in the implementation of the Global Compacts and the possibility of considering them an opportunity for a definitive paradigm shift in the way those actors are developing the EU Treaties guiding principles in the migration and asylum domains (C). A global public goods approach will be then considered (D). My conclusions will be drawn in the final section (E). Since a fundamental change in the underlying assumptions on this field is needed, I will maintain that the global public goods theory can help the relevant actors to take both rational and effective decisions.

\section{(B) TIIEGLOB \LCONP ICTS IS ST IND \RD SETTERS}

(1) The Global Compacts are not legally binding: What does that imply?

The U \ Global Compacts as are not legally binding, which it not an unintentional choice.5The Giobal Compacts express the political ambitions and will of $\mathrm{I}$ Member States. They are human rights-driven and confirm the existing international human rights law and protection frameworks. As it has been said (t)he most remarkable thing about the Global Compact for Safe, Orderly and Regular Migration (...) is that

12 According to the International Organization for Migration a migrant is a person who moves away from his or her place of usual residence, whether within a country or across an international border, temporarily or permanently, and for a variety of reasons. The term includes a number of well-defined legal categories of people, such as migrant workers; persons whose particular Iypes of movements are legally-defined, such as smuggled migrants; as well as those whose status or means of movement are not specifically defined under international law, such as international students. This work will take into account only international migrants: those who move away across an international boundary. The above definition is available electronically at htlps: / www.iom.int who-is-a-migrant, accessed 7 November 2019.

3. The I ACrtIIR understand international protection as the protection that a State offers to a foreign person because, in her or his country of nationality or habitual residence, that individual's human rights are threatened or violated and she or he is unable to obtain due protection there because it is not accessible, available and or effective': see paragraph 37 of the I ACrtIIR Advisory Opinion (OC-21/14, Rights and Guarantees of Children in the Context of Migration and or in Veed of International Protection, adopted on ig August 2015.

‘ G. Noll, 'Prisoner's Dilemma in Fortress Europe: On the Prospects for Equitable Burden-Sharing in the European Union' qo German Yearbook of Inlernalional Law (1997) 405-137.

is S. Carrera, K. Lannoo, M. Stefan and L. Vosvliute, 'Some EU governments leaving the U I Global Compact on Migration: A contradiction in terms?, CEPS Policy Insights Vo. 2018/15, November 2018, available electronically at hllps: /ww.ceps.eu/ceps-publications/some-eu-governments-leaving-un-global-compact-migration-contradiction-terms/, accessed 7 Vovember 20rg. As the authors points out, 'this option allows for a wide degree of flexibility in the implementation phase, while at the same time providing financial support and the possibility for monitoring progress through periodic review' (at 3 ). 
it exists at all.'.' In my opinion, the same can be said about the Global Compact for Refugees. Since they are not legally binding, the implementation process becomes crucial, at they contain political and moral commitments by participating States to pursue its aims.' ${ }^{77}$

The Global Compacts are sofi law instruments ${ }^{18}$ aimed to provide 'governance potential' ${ }^{19}$ and constitute a cooperation framework among States. It goes without saying that not legally binding does not means without legal consequences. Both instruments materialize the political consensus of an important number of States about how international migration and refugee protection should be governed. ${ }^{20}$ Proving that engaging this political consensus was not innocuous, a group of States decided not to participate in the adoption of the GCM and did not attend the International Conference held in Marrakech in December 2018. As known, some of them are EU Member States, which can in fact complicate the adoption of implementation measures at EU level. ${ }^{21}$ By doing so, those States breached the deal reached in 'The European Consensus on Development' where an agreement was made on supporting the elaboration of the U Y Global Compacts on Migration and Refugees. ${ }^{22}$ At the end of the day, the coordination and unity showed during the discussion process could be merely apparent. ${ }^{23}$

(2) Do the Global Compacts aim to enhance legal certainty for people on the move in need of international protection?

16. K. Vewland, 'The Global Compact for Safe, Orderly and Regular Migration: An Unlikely Achievement' 30 Inlernalional Journal of Refugee Law (2018) $657-660$, al 657 .

$17 \quad$ Ibid., al 2.

18 We use the shorthand term soft law to distinguish this broad class of deviations from hard law and, at the other extreme, from purely political arrangements in which legalization is largely absent': K. W. Abbot and I). Snidal, 'I Iard and Soft

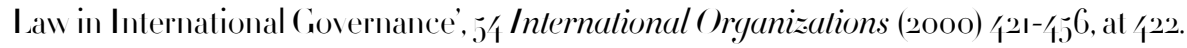

19 M. Panizzon, 'Governance and the U I Global Compact on Migration: Just another Soft Law Cooperation Framework or a \ew Legal Regime governing International Migration?', E.JIL Talk:! published on / March 2org, available electronically at htlps: www.ejiltalk.org governance-and-the-un-global-compact-on-migration-just-another-soft-law-cooperationframework-or-a-new-legal-regime-governing-international-migration, accessed 7 November 2019 .

20 Is Amato has affirmed '(c)onsensus - the inference we draw from the process of international communication about norms - is international law; what states believe to be law is law': G. Amato, 'On Consensus', 8 Canadian Yearbook: of Inlernational Law (1970) 10/-122, at I2I.

${ }^{21}$ See on this question: M. Gatti, 'EU States' Exit from the Global Compact on Migration: A Breach of Lovalts', EU Immigration and Asslum Law and Polies, published on 1/4 December 2018.

${ }_{22}$ Joint statement by the Council and the representatives of the governments of the Member States meeting within the Council, the European Parliament and the Commission, OJ 2017 C $210 / 1$.

${ }_{23}$ Nbout the participation of the EU in the GCM see: P. Melin, The Global Compact for Migration: Lessons for the U nity of EU Representation', 2 I European. Journal of Wigration and Law (2019) 19/-21/. 
Providing legal certaint ${ }^{2 / 1}$ for people on the move can be considered a specific objective of the Global Compacts. The New York Declaration for Migrants and Refugees ${ }^{25}$ intends to facilitate safe, orderly, regular and responsible migration and mobility of people, including through the implementation of planned and well-managed migration policies' and 'the creation and expansion of safe, regular pathways for migration' ${ }^{26}$ and 'to expand the number and range of legal pathways available for refugees to be admitted to or resettled in third countries' ${ }^{27}$. Although two separate Global Compacts were finally adopted, ${ }^{28}$ both instruments stress the need of greatly expanding the possibilities of making international displacements safer.

\section{(a) Legal cerlainly for migranls as a goal in the GCW}

The GCM is truly ambitious. It aims to cover all aspects of international migration. ${ }^{29}$ Providing legal certainty can be considered a transversal objective in this regard. $3^{\circ}$ Enhancing availability and flexibility of pathways for regular migration; addressing and reducing vulnerabilities in migration; strengthening certainty and predictability in migration procedures for appropriate screening, assessment and referral; and strengthening international cooperation and global partnerships for safe, orderly and regular migration, are specific objectives enshrined in the GCM. ${ }^{31}$

The U I Iligh Commissioner for IIuman Rights has interpreted the safe and orderly conditions for migrations enshrined in the GCM and has understood that orderly migration governance (...) should ideally refer to migration measures (...) that provide predictability for migrants and States in order to guard against migration policy responses that are arbitrary or unlawful'. In the same sense, 'safety (...) would refer not just to physical security, but more broadly to the proliferation of an environment in which dignity and human rights are respected, protected and fulfilled' $3^{2}$

i It has been affirmed that the principle of legal certainty is 'the international basis of the rule of law': J. R. Maveiner, "Some realism about legal certainty in the globalization of the rule of law', $3^{1}$ ILouston. Journal of International Law (2008) 27-96, at

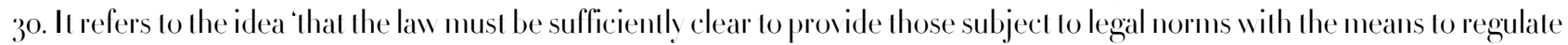
their own conduct and to protect against the arbitrary exercise of public power': Fenwick, M., and Wrbka, S., "The shifting meaning of legal certainty, in M., and M rbka, S. (eds.), Legal Cerlainly in a Conlemporary Conlext: Privale and Criminal Law Perspectives (Springer, The Ilague, 2016) at I.

25 G A Res. 71/1, 19 September 2016.

26. Cfir. paragraph 8 e).

${ }_{27} \quad$ Ibid., al 77 .

28 Cathryn Costello suggests that, even if the Global Compacts 'assume certain categorical distinctions between refugees and migrants' they are 'more fluid they imagine'. She also highlights that 'migration control policies and practices often bear down particularly heavily on refugees and would-be refugees: C. Costello, 'Refugees and (Other) Migrants: Will the Global Compacts Ensure Safe Flight and Onward Mobility for Refugees?', 30 Internalional Journal of Refugee Law (2018) 6/33-6/99. at 6,0 .

29 Guild and Grant, supra n. 10, at 6-7.

30 F. Crépeau, 'Towards a Mobile and Diverse Morld: 'Facilitating Mobility' as a Central Objective of the Global Compace of Migration', $3^{\circ}$ Inlernational Journal of Refugee Law (2018) $65_{5} \mathrm{o}-65_{5} 6$.

${ }_{31}$ See Objectives no. $, 7,12$ and 23 of the GCM.

$3^{2}$ Report on the compendium of principles, good practices and policies on safe, orderly and regular migration in line with international human rights law, I IIRC/, $36 / 42,50$ October 2017. 


\section{(b) Safely for refugees as a goal in the GCR}

The GCR focuses on responsibility sharing ${ }^{33}$ and intends to provide a basis for predictable and equitable burden and joint liability among all U I Member States, together with other relevant stakeholders as appropriate, including regional organizations. ${ }^{31}$ It also underlines the role of regional cooperation in comprehensive responses ${ }^{35}$ and refers to resettlement programs and regional frameworks which may complement national laws in offering pathways to durable legal status or naturalization for refugees as valuable tools. $3^{6}$

\section{(C) TIIE ROLEOFTIIEEL}

Both the GCM and the GCM address important areas of EU migration and asylum policies, which constitute fundamental vectors within the Area of Freedom, Security and Justice. We can find in the Treaty on the Functioning of the EU (TFUE) ${ }^{37}$ references to the adoption of measures regarding the conditions of entry and residence of third country nationals in the $\mathrm{EU}^{38}$ and to partnership and cooperation with third countries for the purpose of managing inflows of people applying for asvlum or subsidiary or temporary protection. ${ }^{39}$ Besides that, and according to article 78 of the TFEU, the European sy stem should conform the 1951 Geneva Convention system. But it does not imply that the Common European Asylum System (CE AS) is the automatic translation of the obligations imposed by the Convention. Member States keep some competences, such as the one related to the possibility of asking for asy lum at Embassies, the establishment of resettlement programs and the issuing of humanitarian visas. ${ }^{\circ}$

Despite these references, the EU and its Member States have developed and prioritized externalization policies and measures, they have tried to contain mobility and a 'fortress Europe' has been

33 Vamed as 'one of the most significant gaps in the international refugee regime': $\mathrm{A}$. Betts, 'The Global Compact on

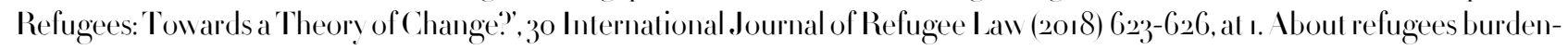
sharing see: P. Schuck, 'Refugee Burden-Sharing: I Modest Proposal', 22 Yale Law .Journal of Inlernational Law (1997) 2/33297 .

31 See paragraph 3 of the GCR.

35 Ibid., at paragraph 28.

$3^{6} \quad$ Ibid., al paragraph 99 .

$37 \quad$ O.J $2012 \mathrm{C}_{32} 6 / 47$.

$3^{8} \quad$ Cfr.art. $\left.79 \cdot 2 \cdot a\right)$

39 Cfr. art. 78.2 .9$)$.

10 In a judgment of 7 March 2017 ( $X$ and X vs. Élal Belge, Case C-638 i6 PPU, ECLI:EU:C:2017:173), the European Court of Justice (EC.J) affirmed that Member States are not required, under EU law, to grant a humanitarian visas to persons who wish to enter their territory with a view to applying for asslum, but they remain free to do so on the basis of their national law. Igain, a decision of the European Court of Human Rights (ECallR) could impose obligations to States parties to the European Convention on Iluman Rights (ECIIR) regarding this question. The case, very similar to the one decided by the EC.J in 2017 , concerns a couple and their wo children, all Svrian nationals, who were refused the short-stav visas for which they had applied to the Belgian embassy in Beirut with a view to seeking asylum in Belgium ( I. I. and Others vs. Belgium, application no. 3599 18). The ECIIIR will decide if the Belgian's authorities' refusal of the short-stay visas requested by a couple, Syrian nationals, and their two children, from the Belgian Embassy in Beirut was contrary to arts. 1, 3, 6 and 13 of the ECIIR. 
firmly promoted'. As it has been said, regarding people in need of international protection, (t)he academic literature has brought to light the role that EU cooperation on migration and asylum matters has played in the development of policy and legal instruments focusing on 'containment' of asylum seekers and refugees in countries of origin or transit' ${ }^{2}$ and creating a continum of precariousness.' ${ }^{13}$ In general, these kind of measures and policies try to avoid international law obligations concerning non-refoulement and the legal and logistical problems associated with the return of those who don't have the right to stay according to international and national law. Some of these policies have been put into question by the case law of the ECIIIR. ${ }^{\text {r }}$

In the particular case of the $\mathbf{E U}$, as a result of the application of common rules, the whole territory is theoretically conceived as a single area or protection. Athough this must include, according to EU law, that people in need of international protection must have access to fair and efficient international protection procedures, this common system has been built projecting its protecting scope to those who have reached the European territory. Besides that, existing EU legislation on legal migration does not really provide for a unified system governing entry into and legal residence in the Member States. Because of that, EU migration and asylum system has been described as a legal framework leading to limited safeguards and legal certainty for vulnerable migrants and significant adverse consequences for access to the EU by those who wish to claim international protection.'.5

There seems to be a contradiction between the purposes established by the treaties and the way they have been put in practice. Those purposes include providing freedom, security and justice not only for those who are present in the EU, but also for those who flee from prosecution, violence or situations of human rights indiscriminate violations and seek international protection in the territory of the EU Member States. These values must be understood as interconnected. In this sense, I consider that freedom should be figured out not only as physical freedom of movement. It also would encompass freedom from legal uncertainty, which would include the freedom of migrants from being victims of human rights violations such as those inflicted by criminal smuggling and trafficking networks. ${ }^{(6}$ Preventing them from entry European territory has to be considered a way of circumvent the international obligations stemming

亿 'A kind of schizophrenia seems to pervade Western responses to asylum seekers and refugees; great importance is atlached to the principle of asylum but enormous efforts are made to ensure that refugees (and others with less pressing claims) never reach the territory of the State where they could receive its protection: M. J. Gilbney, The Elhics and Politics of 1 svlum. Liberal Democracy and the Response to Refugees (Cambridge, Cambridge I niversity Press, 2004), at 2.

12 S. Carrera and R. Cortinovis, 'The EU's Role in Implementing the Global Compact on Refugees', CEPS Paper on Liberly and Securily, 2018-o/, April 2019. About border and migration externalization policies see: A. Sánchez Legido, 'Evernalization and outsourcing of migration controls us. human rights', 37 Revisla Electrónica de Esludios Inlernacionales (2019), 24 PP.

13. A. Veylon, 'Producing Precariousness: 'Safely Elsewhere' and the Removal of International Protection Status under'

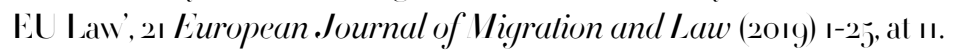

低 Recent and relevant cases are IIirsi.Jamaaa and olhers v. Ilaly, ECIIR (2012) Report of Judgments and Decisions $2012-$ II, and N.I and N.T.v. Spain, ECIIR (2017) ECLI:CE:ECIIR:2017:1003J J Dooo8675.5.

4.5 V. Mitsilegas, The criminalizalion of migralion in Europe. Challenges for human rights and the rule of law (Springer, London, 201/), at 74.

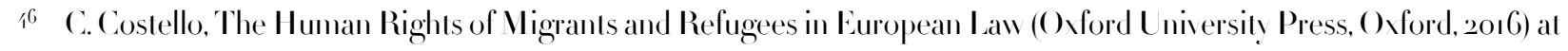
29. 
from the principle of non-refoulement and, subsequently, an infringement of a peremptory norm of

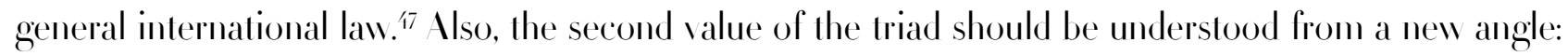
security should be understood in this context as 'human security..$^{8}$

\section{(I) IGLOB ILPUBLICGOODTIEORI IPPRO \CI?}

Migration governance is a matter of international cooperation. As Betts noted in 2011 "(a)s with other transboundary issue-areas, states have increasingly recognized that they are unable to address their concerns with migration in isolation but that forms of collaboration and coordination are necessary. ${ }^{19}$ As to the EU, I think we can affirm that its Member States have effectively cooperated in migration and refugees matters. Although the achievements are to some extent disappointing, an important set of binding rules have been adopted over the years. At least on paper, the EU has tried since 2005 to build a comprehensive policy covering not only border control and the fight against illegal migration, but also addressing the roots on forced migratory movements, enhancing legal opportunities for economic migrants and refugees and improving integration in host societies. These were the goals enshrined in the 'Global Approach to Migration and Mobility' adopted by the European Council in 2005 and incorporated to the Stockholm Programme..$^{\circ 0}$ The same objectives were proposed a decade later in the Valetla Summit on Migration held in November $2015^{5.5}$

Despite the assumption of migration governance being a shared responsibility, the truth is that not much has been done outside the strengthening of security at borders and the externalization of migratory control. Besides that, EU Member States has not shown neither external solidarity -towards third countries and third country nationals-, nor internal. The fact that the mechanism contained in Council Directive $2001 / 5 j$ EC of 20 July $2000^{5^{2}}$ has never been applied is illustrative enough..$^{33}$

Could the global public goods view help to change this tendency by providing a useful theoretical framework to analyse the question of the common implementation of the Global Compacts by the EU and its Member States in order to reduce fragmentation and refugees and migrants'vulnerability? This is the question I will address in this section. Three questions words would constitute the axes of analysis. First, I would try to define global public goods. Second, the reasons backing the need for closer cooperation in

\footnotetext{
17 J. Allain, The jus cogens Vature of non-refoulement', 13 Inlernational Journal of Refugee Law (2001), 533-5.58.

is From a human security, perspective it is crucial to put into place legal protections for people on the move and to establish institutions and structures that can effectively enforce those protections: F. V ietli and T. Scribner, 'Ituman Insecurity: Understanding International Migration from a Iluman Security Perspective, s Journal of Migration and IIuman Securily (2013) $17-3$ 1, al 26.

19 Belts, Introduction..., supra n. 3, al 307 .

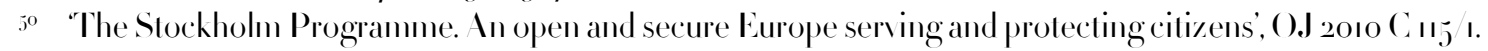

5. The Action Plan and the Political Declaration adopted in Valetta are available here.

$5^{2} \quad$ On minimum standards for giving temporary protection in the event of a mass influx of displaced persons and on measures promoting a balance of efforts between Member States in receiving such persons and bearing the consequences thereof, O.J 2001 L 212 12.

33 M. Ineli-Ciger, Time to Activate the Temporary Protection Directive. Why the Directive can Play a Key Role in Solving the Migration Crisis in Europe', 8 European Journal of Migration and Law (2016) 1-33.
} 
this field will be addressed. Finally, some examples of how this cooperation could be put into practice will be explained. Ultimately, a global public good approach was chosen in order to show that there are good reasons for supporting European deeper cooperation in this field.

(1) What is a global public good?

The term public good is generally understood to be defined by wo characteristies: non-rivalry and nonexcludability. ${ }^{30}$ First, there is no rivalry between potential users of the good: one person State/ society can use it without diminishing its av ailability to others. This means that when the good is consumed, it doesn't reduce the amount available for others. Secondly, people/States/societies cannot be practically excluded from using the good. Thus, it is available to everyone, whether they contributed to producing it or not.

Although public goods have been conceived at national in character ${ }^{55}$, global concerns (i.e. climate change adaptation, fighting against terrorism or non-proliferation of nuclear weapons) inspired an international approach to the concept. Thus, the above-mentioned characteristies have to be reframed from an international perspective. Some legal global public goods depend on the aggregate efforts of, at least, the most influential actors. ${ }^{-6}$ Reducing migration vulnerability through international legal cooperation can be considered an example of this kind of global public goods. It requires an aggregated effort intended to establish an incentive program aimed to make mobility safe for third country nationals.

Barrett warns about the problem of collective efforts. How to persuade States to do more if selfinterest tells them it is time to stop (usually because the costs of acting are going up and could exceed the benefits if a little more is done)? 957 To solve this problem, a complete programme of incentives should be established.

(2) Why should States cooperate in this field?

A recent review of the literature on this topic found that a global public good approach can be useful when it comes to assess the implementation of the rules aiming to establish burden-sharing obligations under the CE AS. ${ }^{8}$ In his analy sis, Tim I Iatton affirms that refugee protection can be considered a global public good if we take into account the benefit for sociely stemming from knowing that a humanitarian crisis has been properly addressed. At the same time, when one State provides safe haven for refugees and other

si I. Kaul, I. Grunberg and M. A. Stern, 'Defining Global Public Goods', in. I. Kaul, I. Grunberg and M. A. Stern (eds), Global Public Goods. International Cooperalion in the ersl century (O) P, Oxford, 1999) 2, at 3.

53 Ibid., al 9.

$5^{56}$ I. Krisch, 'The decay of consent: International Law in an age of public goods', ro8 The American Journal of International Law (201/) I-40, at 1. As this author recalls "(s)ingle-best-effort goods (...) can be provided by a single actor o group of actor's', while weakest-link goods (...) requires action by all, including those less willing or able to do so'.

57 Barrell, supra n. I, at $8 \mathbf{1}-82$.

$5^{8} \quad$ See J. Fernández-Huertas Moraga, 'Can Market Mechanisms Solve the Refugee Crisis?' 2亿\} IZI II orld of Labour (2016) I-10. The author conceives quotas as first step in a three-step process that should include wo other market mechanisms. Second would be a matching scheme letling refugees to specify both preferred and not desired destinations. Third step should be a compensations mechanism were obligations to provide protection to refugees and people in need or international protection could be bought and sold. 
individuals in need of international protection, residents of another countries (in our case, residents both in the rest of Member states and in third countries) would benefit from knowing that that people has found a safe place to be .99

In the same line, Eiko Thielemaan identifies protection of refugees as a public good. Ile highlights that when people in need of international protection find sanctuary, secondary movements of asylum seekers and subsequent border tensions are suppressed. Thus, he maintains that internal security can be considered a public good. ${ }^{60}$ Despite the difficulties for agreeing on a common binding cooperative mechanism in this field," these authors agree on the EU being the best placed international organization to do so. According to them, legal fragmentation arising from the unilateral determination of the conditions and requisites that have to be met to have access to protection/residence for migrants does not take into account the 'global social optimum' (understood here as the best possible solution to the problem of refugees) and can provoke that States assume refugees and people in need of international protection below that optimum.

In my view, this reasoning can be extended to other areas of cooperation regarding human mobility. In general, fragmentation and the lack of legal channels letling access to international protection mechanisms and legal residence for refugees and migrants turn into legal uncertainty for them. Too often, they have to 'trust' in smuggling networks for doing a journey that, because of the absence of precise and clear international obligations assumed by States, they cannot legally do.

Of course, this has adverse effects for people on the move, since they do not travel in adequate and decent conditions, and gives rise to gross violations of human rights. Smuggled and trafficked people, refugees and asylum seekers, or non-accompanied migrant children became more vulnerable. But it has also negative consequences for States, which put up with some adverse side effects in this scenario.

For these reasons, it is very likely that the establishment of a legal multilateral framework providing safe channels for migrants and people seeking international protection in Europe would generate positive externalities.

Since it would turn, for example, in better managed migration flows, States will better control the movements across borders. At the same time, it would facilitate a more efficient fight against organized

59 T. J. Matton, 'Selting Policy on Asylum: Mas the EU Got it Right?' I2/ IZI II orld of Labour (2015), available electronically at https: wol.iza.org articles setting-policy-on-asylum-has-eu-got-it-right long, accessed 7 November 2019.

6o E. Thielemann, 'Why Refugee Burden-Sharing Initiatives Fail: Public Goods, Free-Riding and Symbolic Solidarity in the EU', 56 .Journal of Common Markel Studies (2018) 63-82.

6. As known, following the migratory crisis that took place in 20r, the European Commission proposed to relocate I60.000 persons in need of international protection. The Commission also recommended a structured solidarity mechanism which could be triggered any time by the Commission to help anv EU-Member facing a crisis situation. Nthough two Council

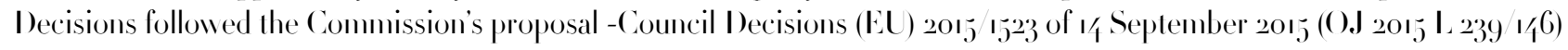
and (EU) $2015 / 601$ of 22 September 2015 (OJ 2015 L 2/18 80 ) establishing provisional measures in the area of international protection for the benefit of Italy and Greece- Member States did not assume the quotas framed at EU level. Some of them even try the annulment of this Decisions before the EC.J. Nthough the Court dismissed the actions, Ilungary and the Slovak Republic -the Member States that brought the cases to Luxembourg- did not relocate the refugees they had been asked. In my view, this made clear the inability of the EU to have its decisions implemented and result in a serious drop of the credibilits of the European Institutions for solving the refugee crisis (see the Judgment of the EC.J of 6 September 2or7, joined cases C-

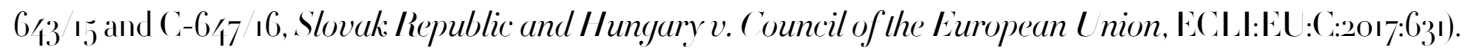


crime (namely the smuggling and trafficking networks). In such case, cooperation is a rational choice. ${ }^{6.2}$ Available data show that, until now, the international community, and the EU in particular, have failed in the objective of making migration and access to international protection safe for individuals. This failure has enhanced the role of mafias and criminal networks in the managing of migration flows. If an European legal framework offers every State's nationals the possibility of enjoying legal certainty when in the move, this will facilitate the achievement of objectives typically related to national and international security. I think we can agree on the idea that the absence of safe access channels to international protection and migration does not fit for the purpose of proving security, for both States and individuals. Only a more open system offering precise legal channels of entry to migrants and refugees could better fit this goal. It would also improve the credibility of the EU's human rights policy abroad and within its territory.

Once in foree, this European regime would benefit to all participants European (and even nonEuropean) States. All of them will enjoy improvements in the fight against organized criminality and border control. Besides that, it seems clear that consumption of the good does not reduce the amount available for consumption by others.

(3) How EU could implement U Y Global Compacts in a consistent and effective way?

In his seminal work Negotialion Asylum, ${ }^{6,3}$ Professor Noll proposes three groups of initiatives to address unequal burden-sharing. First, States could decide to share policies by harmonizing laws. Second, they can choose sharing money through sharing resources. A final option would be sharing physical burdens. That is, sharing people.

In the case of the EU, according to article $4 \mathrm{j}$ ) of the TFEU, the EU and its Member States share the legal competence on issues related to the Area of Freedom, Security and Justice. As a result, the EU has been working in making equal the distribution of refugees and people in need of international protection by harmonizing asylum policies and rules. Ilaving a single area of protection and eliminating internal barriers should have resulted in all the Member States offering the same possibilities and appeal for refugees and people in need of international protection. If we assume that they will seek protection in those countries they consider more accessible of friendly, the harmonization of domestic laws was conceived to avoid this 'asy lum-shopping' approach. In this sense, the Directives on asylum procedures, ${ }^{6,1}$ qualification ${ }^{6,5}$

\footnotetext{
6. Igain, the notion of human security emerges as valuable: '...) the reassessment of security as encompassing broader notions of human security has helped foster a growing recognition of the close relationship between the security of states and the welfare of those living within them': F. Nicholson, 'Protection and empowerment: strategies to strengthen refugees' human security, in A. Edwards and C. Ferstman (eds), I/uman Securily and Non-Cilizens (Cambridge, Cambridge Universily Press, 2010) 82 , al 92

63 Gregor Voll (ed.), Negolialing asvlum. The EU Acquis, Extralerrilorial Prolection and the Common Markel of Deflection (The IIague, Brill Xijhoff, 2000).

6, Directive $20133^{2}$ EU of the European Parliament and of the Council of 26 June 2013 on common procedures for granting and withdrawing international protection, OJ $2013 \mathrm{~L} 18060$.

6.5 Directive 2011/95 EU of the European Parliament and of the Council of 13 December $20 n$ on standards for the qualification of third-country nationals or stateless persons as beneficiaries of international protection, for a uniform status for refugees or for persons eligible for subsidiary protection, and for the content of the protection granted, ( ). 2011 L 3379 .
} 
and reception conditions ${ }^{66}$ aim to offer third country nationals in seek of international protection a homogeneous and equivalent protection. Nevertheless, this goal has not been fully achieved. Different reasons have contributed to this failure. On the one hand, harmonization of refugee (and also migration) has been only partial. As said, in accordance with the shared natured of the competence, Member States keep the competence to legislate an important number of questions. On the other hand, even when a common regulation has been adopted, Member States are often allowed to apply more favourable or flexible conditions at national level. As a result, we count with a non-harmonized regime, where serious differences persist. Besides that, we have to take into account that when it comes to the regulation of human mobility, law is an instrument limited in scope. Even though a more flexible regime legal might favour or encourage mobility, there are other contributing factors. Economic and political trends can also constitute pull and push factors in this regard. ${ }^{67}$

When analysing the question of how could EU and its Member States facilitate access to international protection and safe migratory pathways for third country nationals who are outside the European territory, we have to distinguish between traditional pathways for people in need of international protection and those channels suitable for economic migrants or non-refugee third country nationals.

Regarding the first group of measures and mechanisms, humanitarian corridors, ${ }^{68}$ humanitarian visas, ${ }^{6,9}$ resettlement programs, ${ }^{70}$ and private sponsorship programs ${ }^{71}$ might be included as components of a European binding and permanent framework.

On the other hand, we must take into account that international mobility due to economic reasons falls outside agreed legal regimes on international protection. International law seems had assumed a fundamental difference between forced and chosen migration individual projects. Forced migration is conceived to be related to the flight of people in immediate need of protection. Since their lives are at risk, a prompt and effective answer is perceived as needed. Migration for economic reasons has not gained that level of empathy at international legal level. Thus, economic migration is perceived as chosen and accordingty not forced. For this reason, States tend to limit the entrance of economic migrants making it conditional to labor needs. Severe limitations are not perceived as unfair when it comes to let economic

66 Directive 2013.33 EU of the European Parliament and of the Council of 26 June 2013 laving down standards for the reception of applicants for international protection, O.J L $2013 \mathrm{~L}_{18079} 6$.

${ }^{6}$ Thielemann tell us about other pull factors such as existing migrant networks, geographic location, historic or language lies: Thielemann, supra n. 6o, al 63 .

68 Thumanitarian corridor is used to be defined as a type of temporary demilitarized zone intended to allow the safe transit of humanitarian aid in, and or refugees out of a crisis region': P. Gois and J. Falchi, The third way. Itumanitarian corridor s in peacetime as a (local) civil society response to a EU's common failure', 25 Rev. Inlerdiscip. Mobil. I/um. (2017) 59-75, at 67.

$6_{9}$ See supra, n. 4o. At the EU level, the European Parliament has leaded the political debate regarding the need of legislating in this area. See the Report 'Ilumanitarian visas: Europe added value assessment accompanving the European Parliament's own-initiative report' October 2019.

$7^{\circ}$ According to the United Vations Iligh Commissioner for Refugees (U VICR) resettlement programs imply the transfer of refugees and other individuals in need of international protection from an asylum country to another State (in our case, an EU Member State) that has agreed to admit them and ultimately grant them permanent settlement.

${ }_{7}$ See B. Fernández Burgueño, 'Solicitudes de asilo patrocinadas presentadas en embajadas y consulados: un modelo basado en la experiencia española y en el programa canadiense de "private sponsorship”, 3j. Revisla Electrónica de Estudios Inlernacionales (2018) $32 \mathrm{PP}$. 
migrants in the internal labor markets. Nevertheless, the truth is that economic migrants circumsent legal restrictions and get access to irregular work, which poses problems both to individuals in that situation and to host societies. The former is per se in a vulnerable situation. ${ }^{72}$ At the same time, host countries found themselves deprived of the benefits of regular migration. Labor taxation and a softer integration challenge are only two examples in this regard.

Legal migration frameworks for highly qualified workers, ${ }^{73}$ students and researchers, ${ }^{21}$ family members, ${ }^{75}$ long-term residents, ${ }^{-6}$ non EU -workers, ${ }^{77}$ seasonal workers ${ }^{78}$ and intra-corporate transferees, ${ }^{79}$ have been established at EU level. Vevertheless, none of these instruments impose Member States the obligation of admitting in its territory a certain number of third country national workers. Accordingly, article 70.5 of the TFEU makes it crystal clear that the right of Member States to determine volumes of admission of third-country nationals coming from third countries to their territory in order to seek work, cannot be affected by an EU instrument.

The GCM proposes concrete mechanisms with the purpose of enhancing availability and flexibility of pathways for regular migration. This objective could be implementing through closer cooperation among EU Member States. Free movements regimes, visa liberalization or multiple-country visas and labour mobility cooperation frameworks are actions expressly mentioned in this regard. This could help to diminishing irregular movements towards Europe. As the European Commission highlighted in 2015 (a) clear and well implemented framework for legal pathways to entrance in the EU (...) will reduce push factors towards irregular stay and entry, contribuling to enhance security of European borders as well as safely of migratory flows. ${ }^{80}$

$7^{2}$ The Committee on the Protection of the Rights of All Migrant W orkers and Member of their Families has highlighted in its General Comment Vo. 2 that irregular migrants "generally live in fear of being reported to the immigration authorities by public service providers or other officials, or by private individuals, which limits their access to fundamental human rights, as well as their access to justice, and makes them more vulnerable to labour and other Iypes of exploitation and abuse', General Comment Vo. 2 on the rights of migrant workers in an irregular situation and members of their families, adopted on 28 August

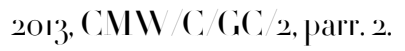

73 Council Directive $20095^{\mathrm{o}}$ EC of 2, May 2009 on the conditions of entry and residence of third-country nationals for the purposes of highly qualified employment, O.j $2009 \mathrm{~L}_{15 . j}{ }_{17}$.

7 Directive (EU) 2016 80 of the European Parliament and of the Council of a May 2016 on the conditions of entry and residence of third-country nationals for the purposes of research, studies, training, voluntary service, pupil exchange schemes or educational projects and au pairing, O.J $2016 \mathrm{~L}_{132} 2 \mathrm{2}$.

75 Council Directive 200386 EC of 22 September 2003 on the right to family reunification, O.J $2003 \mathrm{~L}_{2} \mathrm{~g}^{\mathrm{I}} \mathrm{I}_{2}$.

$7^{6}$ Council Directive $2003 / 109$ EC of 25 Vovember 2003 concerning the status of third-country national who are longterm residents, O.J $2003 \mathrm{~L}_{1} 6 /$ 作. $^{2}$

77 Directive $201198 \mathrm{EU}$ of the European Parliament and of the Council of 13 December $20 n$ on a single application procedure for a single permit for third-country nationals to reside and work in the territory of a Member State and on a common

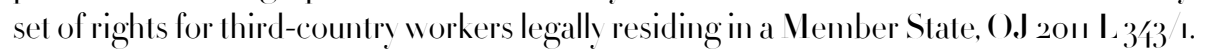

$7^{8}$ Directive 201/4 36 EU of the European Parliament and of the Council of 26 February 201 / on the conditions of entry and stay of third-country nationals for the purpose of employment as seasonal workers, O.J L 20I/ L 94 375.

79 Directive 201/ 66 EU of the European Parliament and of the Council of $y_{5}$ May 201/4 on the conditions of entry and residence of third-country nationals in the framework of an intra-corporate transfer, O.J 201/4 L 157 ı.

so Communication from the Commission to the European Parliament, the Council, the European Economic and Social

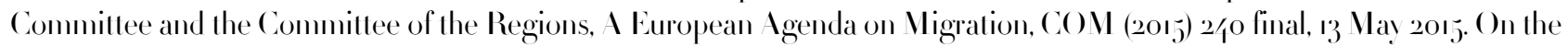


Vevertheless, the proposed advances require further transfer of competences to EU institutions. As Hatton points out, this is "something likely to be seen as yet another threat to national sovereignty ${ }^{8 y_{1}}$

\section{(E) CO\CLUSIOXS: MIICIIPL ICEFORIXCENTINES?}

To a great extent, States still consider enacting laws with the purpose of controlling borders and irregular migration as the last bastion of sovereignty. ${ }^{8_{2}}$ In this paper, I have maintained that a global public goods approach would serve to motivate EU Member States to effectively cooperate in the implementation of the U \ Global Compacts. Both instruments urge States of the International Community to assume an active role in migration governance and protection of refugees. Being a territory of destination for both migrants and people in need of international protection, the EU has a historical responsibility in promoting safety for both groups. For doing so, externalization practices have to be reverted. According to ECRE, these policies could 'directly undermine the success of the GCR' ${ }^{8}$. I think the same can be said about the GCM.

The recent European mismanaging of the refugee crisis has undermined the Organization's credibility. The $\mathrm{V}$ isegrad Group rejection of the quotas, even after the answer given to Itungary and the Slovak Republic regarding the legality of Council Decisions (EU) $205_{5} 1_{5}^{2} 3$ of 1 / September $20 I_{5}$ and (EU) 2015 I601 of 22 September $2015^{81}$, has shown that coercive powers should be strengthened. Due to the fact the only the European Commission and Member States can take legal action before the EC.J under the infringement procedure against a State that fails to implement EU obligations, the possibility of bringing the cases before national courts adds a supplementary judicial mechanism aiming to monitor Member States.

In Spain, the administrative chamber of the Supreme Court decided in its judgment of 9 July $2018^{85}$ that the Spanish Government had partially failed to meet the obligations imposed by the above-mentioned Council Decisions (EU) $2015 / 523$ of $1 / 4$ September 2015 and (EU) $2015 / 601$ of 22 September 2015 . The applicant before the Supreme Court was the Non-Governmental Organization Stop Mare Vostrum. In its judgment, the Supreme Court affirmed that the Spanish State was obliged to continue the relocating processes even after the deadlines contained in the above-mentioned relocation decisions. Also, it maintained that the State cannot be released from its obligations arguing the complexity of the relocation process or the breach of their obligations by other Member States. Thus, it concluded that Spain should

\footnotetext{
links between regular and irregular migration see M. Barslund, M. Di Salvo and L. Ludoph, Can regular replace irregular migralion across the Vedilerranean.' CEPS Project Report, published on 27 June 2019 , accessed 7 Vovember 2019.

8. Mallon, supra n. 59 , al 8.

$8_{2}$ C. Daunergne, Making People Illegal. Ihal Globalizalion Means for Migralion and Law (Cambridge, Cambridge Universily Press, 2008) at 3 .

83 See ECRE, Global Means Global: Europe and the Global Compact for Refugees. ECRE's Recommendations for the Implemenlation of the GCR in and by Europe, published on 23 Vovember 2018, accessed 7 Vovember 2019.

8 , See supra, note 6ı.

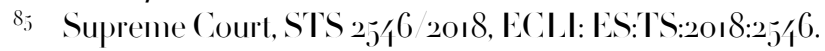


keep on trying to comply with them. Despite the importance of this judgment, ${ }^{86}$ it has to be mentioned that the obligations imposed by the Supreme Court to the State were finally revoked by the writ of the Supreme Court of 20 February 2019 due the material impossibility in relation to the execution of the abovementioned obligations. ${ }^{87}$

Legal certainty for people on the move has been identified here as a common goal enshrined in both instruments. The establishment at EU level of a legal binding regime providing certainty to migrants and people in need of international protection constitutes a global public good that should be provided at EU level. Since the reinforcement of security-related migration policies has resulted not only in an exacerbation of smugglers and traffickers' activity, but also in the erosion of rights of migrants and people in need of international protection, that legal framework would be of benefit not only to third country nationals, but also to EU Member States and their citizens. Besides that, I consider that credibility in the future of the European integration project depends on it being provided.

86 E. Jiménez Pineda, 'The judgment of the supreme court sentencing Spain for failing to duly comply with the council

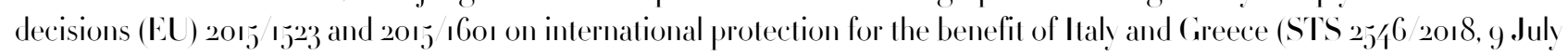
2018)', 22 Spanish Yearbook of Inlernalional Law (2018) 439-4.5.

87 Supreme Court, STS 2/80/2019- ECLI:ES:TS:2019:2/80. 